\title{
Editorial
}

\section{Islamic Dimensions of the East Asian Economic Miracle}

\author{
M. A. Muqtedar Khan
}

\section{In Perspective}

This editorial seeks to identify the missing dimensions of Islamic economics and the Islamic dimensions of East Asian economies. In doing so, it advances a critical review of the present discourse on Islamic economics and highlights some of its oversights. At the outset, it must be clearly understood that I am not critical of the very idea of an Islamic economics. I think that at a time when global intellectual leadership has been usurped by those who consciously subvert the idea of the divine and the role of divine mandates in the organization and governance of human affairs, Islamic economics, like Islamic philosophy and Islamic social sciences, has succeeded in at least presenting a paradigmatic alternative that still maintaines the centrality of transcendence in human existence.

While I am all for sustaining the resistance to secularization of all knowledges, I am critical of the current discourse on Islamic economics because of its disconnection between theory and practice and because, for reasons that have not been explored systematically but are intuitively discernable, it has made Islamic economics synonymous with interest-free banking. Many important elements of Islamic economics are completely ignored or even suppressed. Perhaps this may be a reason why Islamic economies have not really materialized. The importance of these less studied principles can be discerned by studying how they have played a cardinal role in the world's fastest growing region, East Asia. I intend to show how East Asian economies have institutionalized Islamic principles in their contemporary economic practices and are harvesting great benefits. It is ironic that 
the oversight that prohibits most Islamic economists from looking at anything other than interest-free practices has precluded them from even recognizing the existing Islamic practices in "other economies."

\section{The Mythology of Islamic Economics}

The only element of Islamic economics which has enjoyed limited application, is interest-free banking. The limited amount of empirical work one encounters in the discourse on Islamic economics is confined to discussing and fine tuning the problems and extant solutions (like murabaha) of commercial lending without the institution becoming a full partner or a pure lender. The former would discourage deposits and the latter is forbidden. For some mysterious reason, Islamic economists have chosen to make absence of interest and not the abscence of injustice the defining characteristic of an Islamic economy. While usury/riba is indeed forbidden, the widespread assumption that the absence of riba/interest alone is necessary in an economy for it to qualify as Islamic is puzzling.

Despite the growing agreement that interest is riba, I believe that there is more to riba than interest. When we describe riba as interest we do injustice to it by limiting it. In a way, all kinds of isräf (excesses) constitute riba. Anyway, even if we accept that riba and interest are similar institutions, why should it be necessarily absent from an economy. Riba is forbidden for Muslims not non-Muslims, and non-Muslims are not banished from Islamic economies, are they? Even in the early Medina economy, some riba did existent. Muslims were forbidden from taking or giving riba, but non-Muslims, who under the Medinan covenant were allowed to practice their own law, freely gave and took riba. These same non-Muslims also bought and sold goods in the same market places as the Sahabah. Therefore, the Medinan economy was not an Islamic economy if the absence of interest/usury/riba is made a litmus test for defining an economy as Islamic.

The solution to the puzzle of why Islamic economics is reduced to Islamic banking can be gleaned from two contemporary conditions. First, the absence of an Islamic political economy and, second, the lack of autonomous markets/economies. The first is easy to understand. In many parts of the Muslim world the existing political structures are not specifically geared toward realizing an Islamic society. Many of the legal codes have been borrowed/imported wholesale from colonial regimes. Not only are the polities based on non-Islamic jurisprudence, but also the program of 
liberalization of Muslim economies, often dictated by the International Monetary Fund (IMF) and the World Bank or conditional foreign aid, is based on assumptions far from Islamic in their origins. Foreign norms and new economic policies, serving the interests of globalization rather than Islamization, undermine the prospects of Islamic political economies taking root in the Muslim world.

The global economy has increasingly become interdependent. The complex network of exchanges of raw material, intermediate goods, finished products, capital, labor and technology, in addition to the multilayered ownership of the modes of production across borders generating multiple forms of traffic in goods - inter-industry, intra-industry, inter-firm and intra-firm - has made it impossible for any society to carve out an autonomous economic arena where "local norms" can be implemented or enforced. Moreover, the global norms that shape the character of the global economy are dictated by the most powerful players in the system - the United States, Japan, and the European Union. Even though Muslim societies are not as deeply embedded in the interdependent dimension of the global economy (except for the biggest oil exporters), they remain highly dependent on the global economy. Interdependence undermines autonomy and limits the scope for Islamization of economies.

This double jeopardy precludes the development of an Islamic political economy and reduces the role of Islamic principles in the economic arena. While global governance and interdependence prevent the Islamization of economies, they have little bearing on the discourse of economics generated by Muslims. Thus one sees the rapid Islamization of economics without any concomitant practical effect. The growth of oil-generated surpluses in some Muslim countries has allowed some degree of freedom in the banking industry and thus the advances in Islamic economics have translated into limited Islamic banking practices.

While it is easy to understand the conditions which limit the realization of an Islamic economy, namely, the absence of an Islamic political economy and the lack of autonomy, the limits on the discourse are difficult to comprehend. Why has riba alone taken center-stage? Why are other aspects of Islamic economy, such as ' $a d l$ (justice), zakah (distributive justice) prohibition of isräf, falah (welfare), been ignored or marginalized? Why have not issues such as equality of opportunity, public welfare, frugality, charity, just wages, compulsory education, transparency in fiscal policies, ihti$s \bar{a} b$ commissions on $i s r a ̈ f$, discrimination in the work place, poverty allevi- 
ation, redistribution of wealth, attracted the attention of scholars seeking to Islamize economics? There is no evidence either in the Qur'an or the Prophet's (Pbuh) traditions which suggest a hierarchy of Islamic economic values. There is no evidence that riba is worse than isräf or that instituting ' $a d l$ is less important than prohibiting riba? We do know that the Qur'an places social justice as the second most important value after individual virtue $(5: 8)$. So why are we ignoring the issue of justice? Why is Islamic economics not synonymous with "just economics" and not just interest-free banking?

While we are in this critical mood, let us explore other fundamental aspects of Islamic economics. Can we have an Islamic economy without first realizing an Islamic polity? Is Islamic economy autonomous of Islamic governance? Can we have Islamic economic practices while the rest of the society is living according to the Swiss or the French legal codes? What is an Islamic economy? Is it a set of norms or practices of Muslims? Is it necessary that those who claim to practice Islamic economics be Muslims? What it the purpose of Islamic economic principles? Are they given by God to test the believers' commitment to Islam, meaning that they add to the cost of economic transaction and undermine the efficiency of the economy? Or are they principles which enhance the capacity of the economy to fulfill the aspirations of the people and actually contribute to development?

I believe that the principles of Islamic economy as revealed in the Qur'an improve the quality of the economy by encouraging the good and forbidding the harmful. They increase justice, decrease extravagance, increase welfare, decrease exploitation, increase equality and faimess, and undermine discrimination. These are principles that enhance the overall wellbeing of the people. I do not believe that being a Muslim is a prerequisite to implementing these principles and benefitting from them. In the subsequent section, I shall seek to demonstrate that many of the Islamic economic principles, so blatantly ignored in the Muslim world are widely practiced by other societies who have profoundly benefitted by them, in particular by the East Asian economies, whose performance in the last three decades have earned the praise, envy, and admiration of all and has been labeled collectively the "East Asian Miracle."

\section{The Theology of East Asian Economy}

In this section, I intend to explore some of the more widely circulated explanations for the East Asian economic miracle. In doing so, I will iden- 
tify three very important ingredients of the miracle - high savings, consultative decision making, and more even distribution of wealth - and argue that these are indeed the elements one should expect to find in the hypothesized Islamic economy. Sadly, while Muslim economists pay scant attention to these Islamic values, non-Muslims who assiduously adhere to them continue to benefit from their virtues.

The phenomenal development and growth sustained by East Asian economies for over three decades remains one of the most fascinating aspects of the twentieth century. Dubbed repeatedly by World Bank and the IMF as the "East Asian Miracle," the growth of East Asian economies has attracted the attention of scholars from both the East and the West. Developing countries have been trying to model the growth patterns of Japan to emulate them, while Western nations study these economies with fear and uncertainty, as it is becoming increasingly clear that East Asia will eclipse the West in the economic arena. Already Japan, the World's second largest economy, has exceeded all Western countries, in particular the United States, when it comes to indicators of wealth and prosperity such as balance of trade, per capita income, life expectancy, and current reserves.

\begin{tabular}{l|cccccc}
\hline & Size of Economy & GNP Per & $\begin{array}{c}\text { Life } \\
\text { Capita } \\
\text { Expectancy } \\
\text { Country }\end{array}$ & $\begin{array}{c}\text { Current } \\
\text { Account } \\
\text { Balance }\end{array}$ & $\begin{array}{c}\text { Current } \\
\text { Reserves } \\
\text { in Millions }\end{array}$ \\
\hline Japan & 4,772 & 2 & 37,850 & $77 / 83$ & $+65,884$ & 227,018 \\
USA & 7,690 & 1 & 28,740 & $74 / 80$ & $-148,726$ & 134,880 \\
Germany & 2,320 & 3 & 28,260 & $73 / 80$ & $-13,072$ & 105,208 \\
France & 1,526 & 4 & 26,050 & $74 / 82$ & $+20,561$ & 54,651 \\
UK & 1,220 & 5 & 20,710 & $74 / 80$ & $-2,889$ & 37,636 \\
\hline
\end{tabular}

From the World Bank Report on World Development, 1998/1999

Western scholars, particularly after the end of the cold war with Western priorities shifting from security concerns to economic concerns, have pondered the miraculous development of East Asia and its implications for the global economy and the balance of economic power. Many explanations have been advanced. Some superficial and some profound. Regardless of the character or the nature of the narrative, all agree that the outstanding feature has been the sustained nature of East Asian growth. It is not the 
wealth of these societies which is the issue here, it is their ability to identify and institutionalize policies which consistently bring remarkably high growth rates, sometimes even in double digits. ${ }^{1}$

For analytical purposes the East Asian region is usually divided into five subregions. The first subregion is Japan. Japan is very distinct from the rest of the region and in a moment we shall see why. The second subregion consists of South Korea, Taiwan, Hongkong, and Singapore, which are called the Asian Tigers or the NIEs (Newly Industrialized Economies). The third region includes Malaysia, Indonesia, and Thailand. The fourth region is China, and the fifth includes North Korea and the Philippines. Each region has its unique quality.

Japan remains Asia's only nation to have industrialized in the nineteenth century and it actually lagged only four decades behind the English industrial revolution. Japan has been growing in a fashion very similar to the Western world. It too shifted from agriculture to industry in the late nineteenth century, went on an imperial binge and colonized China and Korea and much of the region. It was a principle player in the Second World War and, despite the devastation in that war, continued to grow and prosper. China is a world by itself. It has joined the Asian economic march very late but is doing a great job of catching up. North Korea and the Philippines are remarkable only for their failure to benefit from the overall growth in the region. Malaysia, Indonesia, and Thailand have enjoyed high growths like the NIEs, but unlike the NIEs a lot of it comes from an initial reliance on natural resources. Also their per capita incomes is still below $\$ 10,000$. No doubt they are growing rapidly, but they are not as advanced or as prosperous as the NIEs. Our focus in this editorial is on the NIEs.

\begin{tabular}{l|cccc}
\hline Country & $\begin{array}{c}\text { Growth Rates } \\
\text { 1955-1970 }\end{array}$ & $\begin{array}{c}\text { Growth Rates } \\
\text { 1965-1980 }\end{array}$ & $\begin{array}{c}\text { Growth Rates } \\
\mathbf{1 9 8 0 - 1 9 9 3}\end{array}$ & $\begin{array}{c}\text { Current GNP } \\
\text { Per Capita }\end{array}$ \\
\hline South Korea & 6.7 & 9.9 & 9.7 & 10,550 \\
Hong Kong & 9.6 & 8.6 & 7.1 & 25,280 \\
Singapore & - & 10 & 6.4 & 32,940 \\
Taiwan & 8.7 & 8.9 & 8.8 & 12,400 \\
Malaysia & 5.3 & 7.4 & 5.2 & 4,680 \\
Indonesia & 3.6 & 7.0 & 5.5 & 1,110 \\
Thailand & 6.9 & 7.3 & 7.6 & 2,800 \\
China & - & 6.8 & 9.5 & 860 \\
\hline
\end{tabular}

From the World Bank Report on World Development over the years. 
There are many theories that seek to offer explanations for the miraculous performance of East Asia's NIEs. The simplest explanation, and the one preferred by East Asians, is the political culture argument. This argument suggests that there is something inherent to Confucian values, such as respect for order and harmony, that has facilitated this Asian miracle development and prosperity without the negative aspects of modernity, declining moral values, disintegration of the family structure and growth of crime and drugs, which have plagued Western societies. Indeed, the amazing growth of societies with little or no natural resources, Hong Kong, Singapore, South Korea and Taiwan, is largely due to the diligence, ingenuity and hardwork of their human resources, who have one thing in common - the Confucian way. ${ }^{2}$

In other societies in the region like Indonesia and Malaysia where Islam dominates, natural resources have played as much a role in development as have human resources. For example, oil for Indonesia and tin and rubber for Malaysia. But even in these places, it is the Chinese who have dominated industrialization and most of the investments and technology has come from Chinese conglomerates. But there are many flaws in the political culture agrument. If Confucian values are singularly responsible for the East Asian growth, then why didn't these values provide this growth earlier, why did it happen only after the 1960s? More importantly, why haven't these values vitalized other societies which also adhere to the same principles? Of course, one may argue that once development took place, Asian values may have protected these newly modernized societies from plunging into moral decline like some of the Western societies. But that idea remains a thesis which has not been subject to serious empirical exploration. Nonetheless, the theory of Asian/Confucian values provides Asian leaders with great fodder for their after dinner speeches in foreign capitals but nothing more.

The political economic explanation of the East Asian growth, though inadequate, offers much more important clues to understanding the East Asian miracle. According to this perspective, the two most important elements of the growth have been the role of a benign and authoritarian state that has single mindedly pursued economic growth and the role of the United States, which has provided security guarantees, foreign and development aid, open and unfettered access to its markets without any reciprocal gesture, and a continuous flow of technology from both itself and Japan. $^{3}$ 
The United States has pumped over $\$ 20$ billion dollars in foreign aid into the region, subsidized defense and provided necessary infrastructural support for establishing capitalist economies. Currently, the East Asian Tigers run a positive balance of trade of about $\$ 55$ billion with the United States annually. ${ }^{4}$ The prosperity of Japan has also assisted the region, as it has increasingly become a "Japanese zone of co-prosperity." The fear of NAFTA (North American Free Trade Agreement) and the European Union has driven Japan toward providing more financial support, through FDI (foreign direct investments), ODA (official development aid), consumer lending, and lending through multilateral institutions such as the Asian Development Bank, whose primary sponsors are Japan and the United States. Japan is also opening up its markets for East Asian products by exporting them intermediate goods and important finished goods. But Japan runs a positive trade balance with East Asia and the deficit is made up by the American market. ${ }^{5}$ Thus, in many ways the East Asian miracle is dependent on American and Japanese markets, investments and technology transfers, besides American security guarantees and an open market policy even in the face of heavy trade barriers to American goods.

The international political economy (IPE) approach sheds light on many aspects of the development phenomenon, technology, resources markets, but there are some elements of the process, such as savings rate and frugality, consultative decision making, and equitable distribution of wealth, which cannot be explained through IPE models. These are the elements which are not only crucial for understanding East Asian growth but are also, in my opinion, elements of an Islamic economy. Perhaps these are qualities which the Asian people hold in common due to their common Confucian heritage. But they are found not only in the Chinese dominated East Asian countries but also in Japan, Malaysia, and Indonesia which are predominantly Muslim societies. It is widely accepted that these three elements have played a key function in the East Asian miracle. I humbly submit that these very same elements would also constitute key elements of an Islamic economy.

\section{Islamic Economic Principles: Avoiding Isrāf}

In verses 17:27 and 7:31, the Qur'an condemns isräf or wasteful expenditure. Some Islamic economists also recognize the prohibition of $i s r a \bar{f}$ or the sanction against wasteful expenditure/consumerism as an important principle of Islamic economics. ${ }^{6}$ While richer Muslim societies in the past 
and the present are outstanding for their grandiose consumption patterns, East Asian economies are remarkable for their high savings rates of 30 to 40 percent of GDP, which they have maintained for nearly four decades.? These savings rates play a major role in the miracle of East Asia.

High savings has enabled these societies to finance their own growth and avoid the foreign aid trap which has been the bane of many underdeveloped countries. Many countries, in the hope of sparking growth, have borrowed heavily from foreign countries and multilateral institutions. The debt burden, and sometimes just the cost of servicing these debts, has crippled many economies. But East Asians, thanks to their high savings (sometimes even required, as in Singapore), have managed to finance much of their capital need. Indeed, the enormous capital accumulation which has resulted from these savings has made East Asian economies capable of making foreign direct investments (FDI) in the United States and China. East Asia has shown that avoiding isräf, something which Islamic economists have only talked about as a minor addendum to interest-free banking, can play a significant role in economic growth and autonomous development.

\section{Consultative Governance}

An important principle of Islamic social organization is the principle of shura or consultative decision making. The Qur'an advises Muslims to conduct their affairs through a process of mutual consultation (3:159). The Qur'an also considers as blessed those who conduct their affairs through mutual consultation (42:38). The contemporary discussions among Islamists, Western scholars of Islam, and many Muslim intellectuals about the form democracy would take within an Islamic ethos, centers around the concept of shura. ${ }^{8}$ While there is little clarity on what an Islamic democracy or shurocracy would look like, there is widespread agreement that shura or consultation is not just a desirable but a necessary ingredient of Islamic governance. Given the centrality of consultation to management of Islamic affairs, it is remarkable how little attention Islamic economics/economists pay to shura and its role in Islamic economics.

East Asia now manifests some transition to democracy in Taiwan and South Korean. During the miracle years, they were either single party authoritarian regimes or military dictatorships. Nevertheless, these places demonstrated a remarkable degree of state-society interface and many of the policies advocated by the government were those desired by the economic sector. The social policies also reflected the popular will; therefore, 
these states had little problem in implementing effective policies over decades. The confidence that they were able to generate in the society came from their ability to understand and pursue the goals of the society at large and, therefore, the policy outcomes were more consultative than authoritative. In an interesting fashion, these East Asian states were ruling with both consent and through cooperation of the ruled without actually creating Western style democratic institutions. ${ }^{9}$

The governments created consultative bodies, called advisory committees, which were composed of leaders from the society and the state (bureaucrats and politicians). The governments also facilitated the development of associations and chambers of commerce which became their partners in collecting industry information and devising development strategies to optimize the joint resources of the public and private sector. These consultative bodies (yes! this is exactly what they are called) created multiple levels of interface between the rulers and the ruled, in many ways "tying the hands of the rulers." The governments always sought to build consensus in order to facilitate a harmonious society. ${ }^{10}$ These interfaces helped legitimize the rulers and enabled the ruled to systematically give their input to policy making. Trust and cooperation emerged and state and society became partners in the pursuit of economic development and social welfare. ${ }^{11}$ Henry Rowen, in his "Overview," uses a headline to describe this phenomenon in Qur'anic terms. ${ }^{12} \mathrm{He}$ calls it: "Understanding good and avoiding or abandoning bad policies" resonating the Quranic injunction: "Enjoin what is good and forbid what is wrong"! (31:17).

Consultative governance, or shura, has clearly played a significant role in the miraculous development of East Asian economies. What is striking about this is that East Asian societies have discovered the merits of Islamic decision making either through trial and error or through their own Confucian tradition and have demonstrated its merit.

\section{Distributive Justice}

While there are only seven verses in the Qur'an that prohibit interest $(2: 275,2: 276,2: 278,2: 279,3: 130,4: 161,30: 39)$, there are 60 verses that stipulate, mandate, encourage charity, discuss its virtues and rewards, warn of punishment to those who eschew it, and warn against hoarding it (9:34, $2: 261,2: 265,2: 276,2: 280,30: 39,34: 39,35: 29,57: 11,57: 18,64: 17$, $2: 271,2: 245,5: 12,57: 11,57: 18,64: 17,73: 20,2: 273,2: 83,19: 31,19: 55$, $9: 91,17: 29,2: 3,2: 43,2: 110,2: 177,2: 195,2: 254,2: 267,2: 227,5: 55$, 9:71, 
$13: 22,14: 31,21: 73,22: 41,22: 78,24: 37,24: 55,24: 56,27: 3,30: 38,31: 4$, $33: 33,47: 38,57: 7,57: 10,58: 12,58: 13,63: 10,64: 16,2: 264,2: 266,16: 75$, $4: 38,2: 3,3: 180,2: 215)$. Astonishingly, Islamic economists have overlooked the significance of charity, welfare, redistribution of wealth, and prevention of income inequalities and wealth disparities. If anything, the sheer weight of Allah's interest in charity and distributive justice should have made Islamic economics synonymous with "charitable/welfare/distributively just economics" rather than interest-free banking! Islamic economists have made charity a personal issue, a desirable element of piety but not a necessary element of economy. They study zakat under taxation and not as an organizing principle of society. Of course there are exceptions, like Umer Chapra and M. A. Mannan. Chapra states the importance of distributive justice eloquently. ${ }^{13}$

Hence Islam not only requires the fulfilment of everyone's needs, primarily through a respectable source of earning, but also emphasizes an equitable distribution of income and wealth so that, in the words of the Qur'an "wealth does not circulate only among your rich" (59:7). ${ }^{14}$

Fortunately for East Asia, their economists, unlike contemporary Islamic economists, did not give the short end of the stick to issues of income and wealth equality. Distributive justice has remained an integral aspect of the region's development. From the earliest phase of its development, East Asia has opted for "growth with equality" or "shared growth." Nearly the entire population of each of these countries has benefitted from the regional growth. Indeed, Indonesia's struggle against poverty - where 60 percent of the population had been below poverty levels in 1970 but only only 14 percent in 1993 - is an indication of the region's success in not only eliminating poverty but also in providing a higher lifestyle for a majority of its population. From 1965 till now, all the countries that have combined high growth with high income equality are in East Asia. Distributive justice, while being a worthwhile goal in itself, also has many social and political benefits. It leads to widespread literacy, human development, and reduces tensions between different groups and the possibilities of political unrest and crime. The prosperity and relative internal peace enjoyed by East Asia is a handsome testimony to the virtues of distributive justice. 


\section{Conclusion}

The central thrust of the arguments here is not to undermine the project of Islamic economics, but to underline the oversights in the current discourse. As a discourse, Islamic economics has demonstrated the potential for developing a worldview based essentially on Islamic principles. It has been a great success in this larger task. But unfortunately it has fallen short in achieving the specific goal of articulating a vision of economics that pays equal and appropriate attention to all the Islamic principles that directly and indirectly impinge upon economic issues. Therefore, I have advanced a critique of the contemporary discourse on Islamic economics with the twin purposes of showing how it's singular focus on interest is marginalizing other important elements of Islamic economics such as justice, distributive justice, and consultative decision making, and how other economies are thriving by paying attention to these very principles. The discussion of East Asian development seeks to demonstrate how the Islamic principles of equity, shura, and frugality have benefitted other societies who recognize the merit of these values and have steadfastly sought to implement them.

The success of this editorial lies in a renewed attention to all the important aspects of Islamic economics which have not been as fully developed and operationalized as interest-free banking. The point being that while interest-free practices are essential and important components of Islamic economics, they do not in themselves fully constitute the Islamic economic worldview. Hopefully, this editorial will inspire more correspondence between contemporary economic practices, economic conditions, political realities, and the growing Islamic discourse on Islamization of economics. We hope that in the future Islamic economics will pay greater attention to issues of poverty alleviation, justice, redistribution of wealth and resources, and Islamic forms of governance. More importantly, it is hoped that Islamic economists will not limit their efforts to producing models that only meet their "Islamic criteria," but also devote attention to actual economic development and betterment of Muslim societies.

\section{Notes}

1. Minxin Pei, "Constructing the Political Foundations of an Economic Miracle," in H.S. Rowen (ed.) Behind East Asian Growth: The Political and Social Foundations of Prosperity (London: Routledge, 1998), 39-60.

2. David Martin Jones, Political Development in Pacific Asia (London: Polity Press, 1977), 5-57.

3. Refer to the essays in Robert S. Ross (ed.), East Asia in Transition: Toward a New Regional Order (Boston: M.E. Sharpe, 1995). 
4. See Mike M. Mochizuki, "Japan as an Asia-Pacific Power," 124-159; and Donald S. Zagoria, "The United States and the Asia-Pacific Region in the Post-Cold War Era," in Robert S. Ross (ed.) East Asian In Transition, 160-182.

5. See the essays by James H. Raphael and Thomas P. Rohlen, "How Many Models of Japanese Growth Do We Want or Need," 265-296; and Yutaka Kosai and Fumihide Takeuchi, "Japan's Influence on the East Asian Economies," in Behind East Asian Growth, 297-318.

6. Muhammad Nejatullah Siddiqi, "Muslim Economic Thinking: A Survey of Contemporary Literature," in Khurshid Ahmad (ed.) Studies in Islamic Economics (Liecester: Islamic foundation, 1980), 196. See also M.A. Muqtedar Khan, "The Philosophical Foundations of Islamic Political Economy," American Journal of Islamic Social Sciences vol. 13, 3 (Fall 1996): 389-400.

7. Henry S. Rowen, "The Political and Social Foundations of the Rise of East Asia: An Overview," in H. S. Rowen (ed.) Behind East Asian Growth, 7.

8. John Esposito and John Voll, Islam and Democracy (Oxford University Press, 1996), 27.

9. See Henry L. Root, "Distinctive Institutions in the Rise of Industrial Asia," in Rowen (ed.) Behind East Asian Growth, 60-75; and Minxin Pei, "Constructing the Political Foundations of an Economic Miracle," Rowen (ed.) Behind East Asian Growth, $39-60$.

10. David Jones, Political Development in Pacific Asia, 55-57.

11. Henry L. Root, "Distinctive Institutions in the Rise of Industrial Asia," in Rowen (ed.) Behind East Asian Growth, 60-75.

12. Rowen, "An Overview," 18.

13. M. Umer Chapra, Islam and the Economic Challenge (London and Virginia: Islamic Foundation and the International Institute of Islamic Thought, 1995). M.A. Mannan, Economic Development and Social Peace in Islam (London: TaHa Publishers, 1989).

14. M. Umer Chapra, Islam and the Economic Challenge, 212. 